\title{
Coking Properties of Tavantolgoi Coal from Mongolia
}

\author{
J. Dugarjav ${ }^{1}$ B. Tomorchuluun ${ }^{2}$, Byambagar Batdelger ${ }^{3 *}$ \\ ${ }^{1}$ Institute of Chemistry and Chemical Technology, Mongolian Academy of Sciences, Ulaanbaatar, Mongolia \\ ${ }^{2}$ Ulaanbaatar City Admistration, Ulaanbaatar, Mongolia \\ ${ }^{3}$ Mongolian University of Science and Technology, Ulaanbaatar, Mongolia \\ Email: *b_byambagar@yahoo.com
}

Received May 22, 2012; revised June 24, 2012; accepted July 3, 2012

\begin{abstract}
Main technical and structural characteristics of Tavantolgoi coal from Mongolia are determined. Type, code number and other valuable technological indexes of the coal are estimated according to the international classification system of coals. Cokes obtained in a laboratory chamber stove and in a reactor was characterized.
\end{abstract}

Keywords: Tavantolgoi Coal; Coking; Coal Charge

\section{Introduction}

There are substantial coal reserves including high quality coking, hard stone and brown coals in Mongolia, which provide the majority of the current energy requirement and will play a key role in the future economic development of the country [1].

There are wide distribution of coal deposits in all territory of Mongolia more than 300 coal deposits with approximately 150 billion tons of geologically estimated capacity. At present time Mongolia is among the 15 coal richest countries in the world by the coal resources.

A range of coals are commercially available and these include coking coal from Tavantolgoi, bituminous coals from Nalaikh and Shariingol, and lignite coals from the Shivee Ovoo and Baganuur deposits. All these coal deposits except Tavantolgoi locate in the central economic region of Mongolia and are exploiting extensively. The Tavantolgoi coal deposit is interesting and important for the future economic development of Mongolia, with 6 billion tons coal reserves, including 1.5 billion tons of coking coals, distributed in 18 coal bearing layers and has a total thickness of the coal vein of $190 \mathrm{~m}$. The Tavantolgoi coal deposit locates in the south Gobi of Mongolia, about $600 \mathrm{~km}$ to the south of Ulaanbaatar city in the border area with China. It is interesting that the Tavantolgoi coal mine is an open-cast mine and this coal deposit belongs to the Permian formation. This deposit was discovered and investigated by the Russian and Mongolian geologists in 1966 [2]. At present time there are two main boreholes (IV and VIII) are opened and exports coal to China by trucks and using for the local energy demands.

"Corresponding author.
The increased demands and utilization of coal will assist with the economic development of Mongolia. Therefore Mongolian Government pays much more attention for increasing coal exports, development of coal processing routes involving coal washing and coking could potentially play an important role in the near term. Now Mongolian Government is working out a National program for future utilization of Tavantolgoi coal including development of coal transport and infrastructure, building up coal washing and coking factories. Certainly this program attracts attentions of foreign investment for the development of coal processing industry in Mongolia.

Until nowadays the coal of Tavantolgoi deposit has not been characterized in detail in respect to its coke forming properties. For this reason the coal of Tavantolgoi deposit investigated according to its coking ability in a close collaboration with the Czeck Institute of Geoengineering, Prague.

\section{Experimental}

Analytical and technological coal samples of Tavantolgoi deposit were prepared from the geological boreholes number 1141, 1141A, 1338 and 1357. These boreholes belong to following coal viens: 1141 - coal layer IV with depth of $41.5-49.8 \mathrm{~m} ; 1141 \mathrm{~A}$ - coal layer IVA with of depth 128 - $136 \mathrm{~m}$; 1338 - coal layer VIII with depth of 211 - $289 \mathrm{~m} ; 1357$ - coal layer VIII with depth of 175 $204 \mathrm{~m}$. In total, 34 coal samples have been prepared and investigated from these coal layers.

Proximate and ultimate analysis of Tavantolgoi coal samples have been determined according to Mongolian National Standards (MNS): MNS 652-79 (A $\left.\mathrm{A}^{\mathrm{a}}\right)$; MNS $654-79\left(\mathrm{~V}^{\mathrm{daf}}\right)$. 
For the determination of vitrinite (V), liptinite (L), inertinite (I) reflectance values and coal types, micropetrological analysis of these coal samples were performed according to Czeck National Standard (CNS): CNS 441345 and ISO 7404.

Prior to determination of technological coking properties of Tavantolgoi coal the mineral content (ash) was decreased to $\mathrm{A}^{\mathrm{d}}<10 \%$ by using heavy organic liquids with specific gravity of $1.4-1.45 \mathrm{~g} / \mathrm{cm}^{3}$ also according to CNS 441351.

For the laboratory and pilot scale coking experiments of Tavantolgoi coal samples, the following coal charges (A, B, C, M) were prepared: A-from samples of coal layer IVA; B-from samples designated as 04, 06 and 08 of coal layer IV; C-from the remaining samples of the coal layer IV; M-from the samples of the coal layer VIII (boreholes 1338 and 1367).

Laboratory coking experiments of these coal charges were carried out in a "Gor-2" reactor with catching equipment for volatile products during coking process. Pilot scale experiments were performed in a chamber stove of "Pokomy" and "Koligo" which were built up according to British Coal Research Association model.

\section{Results and Discussion}

The proximate and ultimate analysis, petrographic composition, and coking properties of the coal samples from Tavantolgoi deposit have been determined and all results are presented in Table 1. The proximate and ultimate analysis results in Table $\mathbf{1}$ show that coals at different layers and depths have higher content of C $(84.9 \%$ $88.8 \%)$, lower content of H $(4.91 \%-5.13 \%)$, S $(0.45 \%$ $1.30 \%)$ and volatile matter $(26.44 \%-33.6 \%)$ which are the characteristics of a high quality bituminous coking coal with higher thermal stability. According to the ash content coal samples of different layers and depths have wide range of value $(11.4 \%-49.3 \%)$ and it can be decreased by enrichment with heavy organic liquids up to $6.5 \%-9.4 \%$.

In the case of petrographical analysis results in Table 1 coal samples contain $32 \%$ - 66\% of vitrinite, $35 \%$ $64 \%$ inertinite and 3\% - 6\% liptinite and having a reflectance value of Ro $=0.98$ which are also the characteristics of high quality bituminous stone coal. On the basis of these data the coal of Tavantolgoi deposit can be characterized by the coal mark $G$ and international classification number 522 and 534.

According to the analysis results of coking properties of coal samples in Table 1 the sample from IVA layer at the depth of 129 - 136 m demonstrates with best coking properties. $(\mathrm{SI}=6 ; \mathrm{RI}=55$, dilatometric measurements a $=23, \mathrm{~b}=75)$ and characterizes with coal mark $\mathrm{G}$ and code number 534. And this coal can be used as a main coal charge component for coking.

In contrast, the coal sample 01 from the coal layer IV characterizes with poor coking properties and it can be caused by the comparatively higher content of oxygen$8.26 \%$ in it. The higher content of oxygen influences for oxidative thermal processes in the surface zone of the coal sample and it depends also by the higher mineral content of the coal sample. For the most of coal samples from boreholes 1338 and 1357 with characteristics of Ro $=0.82 \%-0.90 \%$ and $\mathrm{V}^{\mathrm{daf}}=28.8 \%$. They can belong to the coal mark $\mathrm{G}$ and code number 534 .

The prepared charges (A, B, C, M) for coking of Tavantolgoi coal samples have been tested in a laboratory

Table 1. Chemical technological characteristics of Tavantolgoi coals.

\begin{tabular}{|c|c|c|c|c|c|c|c|c|c|c|c|c|c|c|c|}
\hline \multirow{3}{*}{$\begin{array}{l}\text { Boreholes } \\
\text { (coalveins) }\end{array}$} & \multirow{3}{*}{ Depth. m } & \multirow{2}{*}{\multicolumn{3}{|c|}{ Petrographic composition }} & \multirow{2}{*}{\multicolumn{5}{|c|}{ Technical and elemental analysis, \% }} & \multicolumn{4}{|c|}{ Coking properties } & \multirow{3}{*}{ Coal mark } & \multirow{3}{*}{ Code number } \\
\hline & & & & & & & & & & \multirow{2}{*}{ SI } & \multirow{2}{*}{ RI } & \multicolumn{2}{|c|}{$\mathrm{D} /$ tatometer } & & \\
\hline & & $\mathrm{V}$ & $\mathrm{L}$ & I & $A^{d}$ & $\mathrm{~V}^{\text {daf }}$ & $\mathrm{S}_{\mathrm{t}}^{\mathrm{d}}$ & $\mathrm{C}^{\text {daf }}$ & $\mathrm{H}^{\mathrm{daf}}$ & & & $\mathrm{a}$ & $\mathrm{b}$ & & \\
\hline $1-141$ & $128-129$ & 32 & 4 & 64 & $24.2 / 7.1$ & 26.76 & 0.45 & 88.0 & 4.97 & 2 & 18 & 36 & 5 & $\mathrm{~J}-\mathrm{KJ}$ & 412 \\
\hline \multirow[t]{3}{*}{ /IVA/ } & $129-132$ & 64 & 3 & 33 & $14.8 / 6.5$ & 28.44 & 1.30 & 87.3 & 5.08 & 4 & 31 & 8 & 69 & $\mathrm{~J}$ & 524 \\
\hline & $132-136$ & 64 & 3 & 33 & $14.57 / 7.5$ & 28.8 & 0.75 & 88.32 & 4.95 & 8 & 55 & 23 & 75 & $\mathrm{~J}$ & 534 \\
\hline & $40-41$ & 48 & 3 & 49 & $21.6 / 9.3$ & 26.5 & 0.22 & 86.83 & 4.91 & 1 & 4 & 34 & 5 & $\mathrm{~J}-\mathrm{KJ}$ & 410 \\
\hline $1-141$ & $41-48$ & 55 & 3 & 42 & $13.4 / 8.4$ & 29.02 & 0.78 & 87.9 & 5.05 & 3 & 28.8 & 18.2 & 28 & $\mathrm{~J}$ & 523 \\
\hline /IV/ & $48-50$ & 66 & 3 & 31 & $11.4 / 6.6$ & 29.6 & 0.70 & 87.9 & 5.13 & 6 & 62 & 9 & 12 & $\mathrm{~J}$ & 534 \\
\hline 1338 & $211-216$ & 49 & 6 & 45 & $18.5 / 8.5$ & 28.3 & 0.69 & 87.3 & 5.07 & 1 & 30 & 17 & 17 & G & 511 \\
\hline \multirow[t]{2}{*}{ /VIII/ } & $217-289$ & 47 & 4 & 49 & $22.1 / 8.6$ & 29.0 & 0.67 & 85.7 & 5.0 & 6.2 & 31 & 17 & 79 & G & 534 \\
\hline & $289-292$ & 44 & 4 & 52 & $49.3 / 9.1$ & 29.5 & 0.98 & 87.8 & 5.02 & 6.0 & 33 & 24 & 105 & G & 534 \\
\hline 1357 & $175-200$ & 40 & 5 & 55 & $22.4 / 9.02$ & 31.5 & 0.97 & 84.9 & 5.1 & 7 & 16 & 13 & 57 & G & 534 \\
\hline /VIII/ & $202-204$ & 47 & 3 & 50 & $16.2 / 8.6$ & 33.6 & 0.87 & 84.1 & 5.2 & 2 & 12 & 18 & 18 & $\mathrm{G}$ & 511 \\
\hline
\end{tabular}

Note: $\mathrm{A}^{\mathrm{d}}$ at numerator is for original sample and $\mathrm{A}^{\mathrm{d}}$ at denominator is for beneficated coals. Where: V: vitrinite; L: liptinite; I: inertinite. 
model coking equipment at different conditions and the determined main characteristics of the obtained cokes, which are presented in Table 2. A preliminary test in a rotating drum "micum" and "irsid" showed a rather low mechanical strength and high grateness of the cokes. Therefore they have been taken some additional steps to get better mechanical properties of cokes, such as decreasing the quantity of fine particles of the charges, drying and adding of pitch to the charges. Granulometric analysis of obtained coke (Table 2) shows that mechanically non strengthened charge "B" prepared from coals with low coking properties has the largest grains in the resulting coke. The coal charge " $\mathrm{M}$ " have been coked in three different conditions: poured humid (Table 2 trials M1-M3); poured dry (Table 2 trials M4-M6) and rammed humid (Table 2 trials M7-M8). As it was expected the cokes from the mechanically pre-strengthened coal charges characterize with lowest porosity (Pr) and highest density $\left(d_{a}^{d}\right)$.

A comparatively high charge density $\left(\gamma=806\left[\mathrm{~kg} / \mathrm{m}^{3}\right]\right)$ was achieved in the case of charge " $\mathrm{C}$ " by shaking after filling it. This coal charge was coked in so called "Gor-2" laboratory reactor at different heating rates (W) and the yields of obtained coke (1), tar (2), pyrogenic water (3), gases (4) and compositions of tar and gases are presented in Table 3.

The results in Table 3 show that more volatiles are formed and less coke is yielded in the conditions with higher heating rates. The yield of coal tar of about 7.8\% $9.6 \%$ is a good agreement with the coal mark and conditions of coking. Also an increase of hydrogen, ethylene, propylene yields and a decrease of methane yield at highest rates of heating temperatures are in a good correlation with theoretical expectations. Noteworthy is also a decrease of oxygen and simultaneous increase of carbon content in coal tar when $\mathrm{C} 1$ and $\mathrm{C} 2$ or $\mathrm{C} 4$ trials are compared.

The coal charge " $\mathrm{M}$ " with better coking properties (code number 534) than the coal charge "C" (code number 523) was also treated for coking trials M9-M11 at different variables in the same reactor "Gor-2" with heating rate $\mathrm{W}_{350-500}$. The final coking temperature in the case of M9-M11 trials was lower than in C1-C4 series and maturity of the obtained coke $\left(\mathrm{R}=1050-2695 \pi \mathrm{min}^{2} \cdot \mathrm{m}^{-1}\right.$; $\left.\mathrm{H}^{\mathrm{daf}}=0.31 \%-0.42 \%\right)$ and its structural strength $\left(\mathrm{P}_{\mathrm{a}}=\right.$ $70.2 \%-84.4 \%$ ) were quit satisfied. From the above mentioned data we can conclude that all coal samples prepared from the four boreholes of Tavantolgoi coal have

Table 2. Conditions and results of pilot scale coking experiments of coal charges A, B, C, M.

\begin{tabular}{|c|c|c|c|c|c|c|c|c|c|c|c|c|c|c|}
\hline \multirow{2}{*}{ Trials } & \multicolumn{5}{|c|}{ Conditions of coking } & \multicolumn{9}{|c|}{ Coke characteristics } \\
\hline & $\mathrm{W}_{\mathrm{t}}^{\mathrm{r}}, \%$ & $\gamma, \mathrm{kg} / \mathrm{m}$ & $\mathrm{t},{ }^{\circ} \mathrm{C}$ & $\tau, \min$ & $W_{350-850} \mathrm{C} / \mathrm{min}$ & $\mathrm{A}^{\mathrm{d}}, \%$ & $\mathrm{C}^{\mathrm{daf}}, \%$ & $\mathrm{H}^{\mathrm{daf}}, \%$ & $\rho, \Omega \cdot \mathrm{mm}^{2} / \mathrm{m}$ & $\mathrm{D}, \mathrm{mm}$ & $\mathrm{d}_{\mathrm{a}}^{\mathrm{d}}, \mathrm{g} / \mathrm{cm}^{3}$ & $d_{r}^{d}, g / \mathrm{cm}^{3}$ & $\mathrm{P}_{\mathrm{r}}, \%$ & $P_{a}, \%$ \\
\hline A & 6.8 & 702 & 1018 & 168 & 10.6 & 11.4 & 97.6 & 0.31 & 2335 & 47.9 & 1.056 & 1.985 & 46.8 & 65.4 \\
\hline B & 10.2 & 706 & 1025 & 192 & 10.0 & 13.11 & 97.95 & 0.2 & 2470 & 51.3 & 1.020 & 1.970 & 48.2 & 72.3 \\
\hline $\mathrm{C} 1$ & 1.4 & 806 & 1103 & 340 & 4.4 & 10.52 & 97.25 & 0.36 & 3055 & 49.2 & 0.929 & 1.828 & 49.2 & 75.2 \\
\hline $\mathrm{C} 2$ & 1.9 & 806 & 1116 & 240 & 6.3 & 10.50 & 97.61 & 0.29 & 2515 & 45.7 & 0.874 & 1.847 & 52.7 & 71.1 \\
\hline $\mathrm{C} 3$ & 2.9 & 806 & 1100 & 240 & 6.7 & 10.40 & 97.41 & 0.45 & 3240 & 39.4 & 0.876 & 1.836 & 52.3 & 65.0 \\
\hline $\mathrm{C} 4$ & 2.4 & 806 & 1068 & 160 & 7.5 & 10.62 & 97.21 & 0.49 & 3755 & 38.2 & 0.873 & 1.842 & 52.6 & 62.9 \\
\hline M1-M3 & 10.7 & 511 & 1014 & 203 & 16.0 & 13.9 & 96.25 & 0.65 & 3313 & 37.7 & 0.970 & 1.866 & 47.5 & 64.1 \\
\hline M4-M6 & 1.3 & 552 & 1009 & 209 & 8.36 & 14.9 & 96.58 & 0.52 & 3353 & 43.8 & 1.110 & 1.883 & 41.1 & 70.6 \\
\hline M7-M8 & 8.5 & 975 & 1010 & 227 & 11.45 & 13.4 & 97.17 & 0.46 & 2512 & 42.15 & 1.200 & 1.890 & 36.0 & 80.8 \\
\hline
\end{tabular}

Where: $\gamma$ : charge density; $\tau$ : coking time; $\rho$ : maturity of coke; $W_{350-850}$ : average heating rate; $D$ : average grateness of coke; $d_{a}^{d}:$ apparent density; $d_{r}^{d}:$ true density; $\mathrm{P}_{\mathrm{r}}$ : porosity; $\mathrm{P}_{\mathrm{a}}$ : structural strength.

Table 3. The yields of products and their properties in the laboratory coking experiments of the $\mathrm{C}$ and $\mathrm{M}$ coal charges.

\begin{tabular}{|c|c|c|c|c|c|c|c|c|c|c|c|c|c|c|c|}
\hline \multirow{2}{*}{ Trials } & \multirow{2}{*}{$\mathbb{W},{ }^{\circ} \mathrm{C} / \mathrm{min}$} & \multicolumn{4}{|c|}{ Yield of products, $\%$} & \multicolumn{4}{|c|}{ Coal tar composition } & \multicolumn{5}{|c|}{ Gas composition, $\%$} & \multirow{2}{*}{$\mathrm{Q}_{\mathrm{s}} \mathrm{kJ} / \mathrm{m}^{3}$} \\
\hline & & 1 & 2 & 3 & 4 & $\mathrm{C}^{\mathrm{d}}, \%$ & $\mathrm{H}^{\mathrm{d}}, \%$ & $\mathrm{O}_{\mathrm{d}}^{\mathrm{d}}, \%$ & $\mathrm{~d}, \mathrm{~g} / \mathrm{cm}^{3}$ & $\mathrm{H}_{2}$ & $\mathrm{CH}_{4}$ & $\mathrm{CO}$ & $\mathrm{C}_{2} \mathrm{H}_{4}+\mathrm{C}_{2} \mathrm{H}_{6}$ & $\overline{\mathrm{C}_{3}-\mathrm{C}_{4}}$ & \\
\hline $\mathrm{C} 1$ & 4.4 & 75.0 & 7.8 & 1.8 & 11.1 & 79.98 & 8.61 & 9.04 & 0.994 & 58.51 & 30.42 & 4.61 & 3.21 & 1.76 & 24391 \\
\hline $\mathrm{C} 2$ & 6.3 & 74.0 & 9.1 & 2.2 & 10.1 & 83.06 & 8.54 & 6.25 & 0.983 & 61.62 & 27.50 & 4.56 & 2.89 & 1.37 & 22840 \\
\hline $\mathrm{C} 4$ & 7.5 & 73.6 & 9.6 & 1.8 & 9.4 & 83.30 & 8.70 & 6.15 & 0.935 & 62.41 & 26.81 & 4.70 & 2.69 & 1.16 & 22335 \\
\hline M9 & 2.5 & 78.6 & 6.0 & 1.5 & 10.9 & 78.74 & 7.79 & 12.15 & 0.990 & 62.40 & 22.10 & 5.10 & 2.10 & 2.10 & 21083 \\
\hline M10 & 8.5 & 76.5 & 6.5 & 2.8 & 12.4 & 81.12 & 7.48 & 9.93 & 9.060 & 63.60 & 20.00 & 5.00 & 2.50 & 2.50 & 21038 \\
\hline M11 & 8.3 & 76.2 & 7.5 & 2.3 & 11.5 & 82.13 & 7.77 & 8.50 & 1.050 & 66.20 & 21.20 & 5.20 & 2.20 & 2.10 & 21251 \\
\hline
\end{tabular}

Where: 1 : coke; 2 : coal tar; 3 : pyrogenic water; 4 : gases. 
coking characteristics suitable for production of metallurgical lump cokes.

\section{Conclusions}

1) According to the determined results of proximate, ultimate and petrographical analysis the coal of Tavantolgoi deposit characterizes with the coal mark $G$ and international classification code number 522 - 534;

2) On the basis of coking experiments in laboratory coking equipments and determined main technical properties of obtained cokes of all coal samples of Tavantolgoi deposit have coking characteristics suitable for production of metallurgical lump cokes;

3) To obtain normal coke from the coals of with J and KJ marks of Tavantolgoi deposit with lower coking properties can be processed by additional treatment such as increasing of thickening and mechanical strength of the coal charges.

\section{Acknowledgements}

Dr. J. Dugarjav would like to thank the Institute of Geoengineering, Prague, Czeck Republic for the travel grant and support for his visit.

\section{REFERENCES}

[1] B. Purevsuren, "Coal the Main Source of Energy in Mongolia," Proceedings of the Second Korean and Mongolian Energy Conference, Seoul, 26-29 June 2007.

[2] D. Bat-Erdene, A. Chimeddorj and R. A. Sharkov, "Sovetsko-Mongolskoe Sotrudnichestvo v Oblasti Geologii. Itogi I Prespectivy," VNII Zarubezhgeologiya, Moscow, 1986, pp. 55-60. 